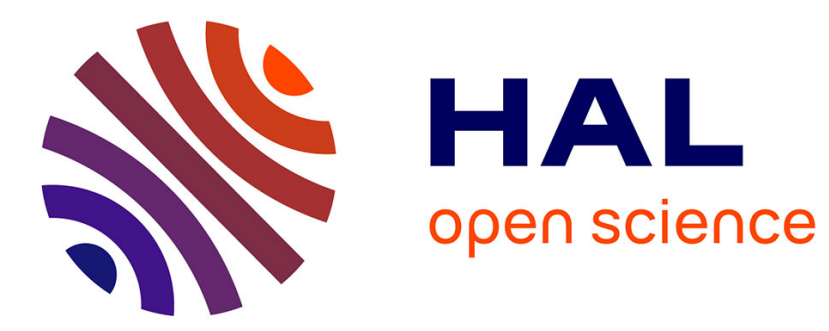

\title{
Integrating ecodesign by conducting changes in SMEs
}

Stephane Le Pochat, Gwenola Bertoluci, Daniel Froelich

\section{To cite this version:}

Stephane Le Pochat, Gwenola Bertoluci, Daniel Froelich. Integrating ecodesign by conducting changes in SMEs. Journal of Cleaner Production, 2006, 15, pp.671-680. 10.1016/j.jclepro.2006.01.004 . hal01205579

\section{HAL Id: hal-01205579 \\ https://hal.science/hal-01205579}

Submitted on 25 Sep 2015

HAL is a multi-disciplinary open access archive for the deposit and dissemination of scientific research documents, whether they are published or not. The documents may come from teaching and research institutions in France or abroad, or from public or private research centers.
L'archive ouverte pluridisciplinaire HAL, est destinée au dépôt et à la diffusion de documents scientifiques de niveau recherche, publiés ou non, émanant des établissements d'enseignement et de recherche français ou étrangers, des laboratoires publics ou privés. 


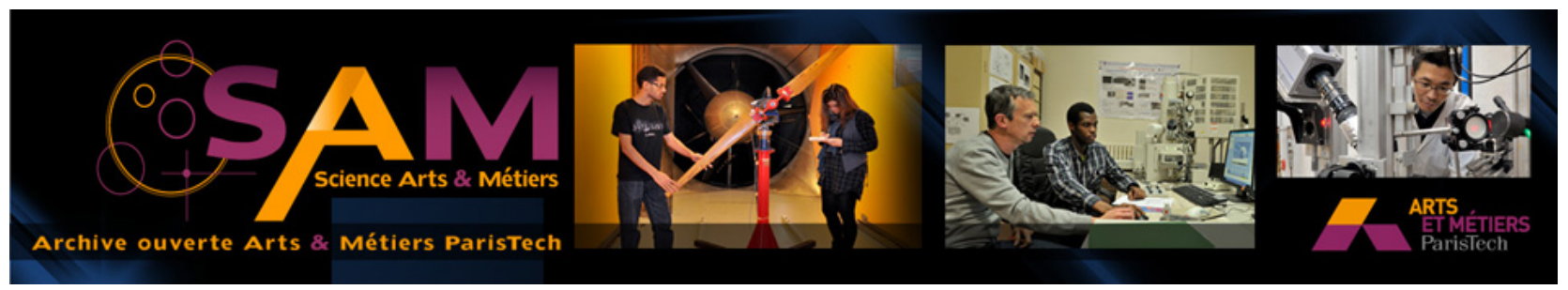

Science Arts \& Métiers (SAM)

is an open access repository that collects the work of Arts et Métiers ParisTech researchers and makes it freely available over the web where possible.

This is an author-deposited version published in: http://sam.ensam.eu

Handle ID: .http://hdl.handle.net/10985/10175

\section{To cite this version :}

STEPHANE LE POCHAT, Gwenola BERTOLUCI, Daniel FROELICH - Integrating ecodesign by conducting changes in SMEs - Journal of Cleaner Production - Vol. 15, p.671-680 - 2006 


\title{
Integrating ecodesign by conducting changes in SMEs
}

\author{
Stéphane Le Pochat*, Gwenola Bertoluci, Daniel Froelich \\ ENSAM Institute, BP 295, 73375 Le Bourfet du Lac Cedex, Chambe'ry, \\ France
}

\begin{abstract}
Despite the progressive use of ecodesign in the industrial world, taking into account environmental constraints remains problematical for small and medium sized enterprises (SMEs), which seem to be remaining on the fringe of the movement. Beyond the lack of environmental culture in the enterprises, the problem stems from the ecodesign tools which have not been designed with any thought of integrating them into the enterprises' organisation. There is indeed no method for ecodesign integration in companies. We show in this article that, while in fact there is a thorough and varied set of ecodesign tools available, they will not allow ecodesign to become more widespread while they remain tools for experts. We are therefore putting forward a method to carry out the integration of ecodesign in SMEs during demonstration projects implemented with the assistance of advisory centres specialised in the industrial sector of the company.
\end{abstract}

Keywords: Ecodesign; Environmental analysis; Ecodesign integration; SMEs; Change management

\section{Introduction}

Sustainable development, the principle of which was stated in 1987 [1] has reached a period of maturity as regards implementing its principles. One of the surest means of achieving sustainable development in our consumer society is to design "ecological" products and services. Eco-designing products indeed encourages a global approach designed to prevent or minimise impacts emerging throughout the whole life cycle of products and concerning all types of environmental impacts.

Thus, during the last 10 years, the efforts linked to integrating environmental constraints in the design of products are becoming industrial reality. This is mainly the consequence of a statutory framework established concerning the environmental responsibility of manufacturing industries, which has been fostered at the European Union level by directives concerning wide categories of products.

The first directives concerning ecodesign of products applied, in principle, to companies responsible for producing

\footnotetext{
* Corresponding author. Tel.: +33479253670.

E-mail address: stephane.lepochat@chambery.ensam.fr (S. Le Pochat).
}

products targeted by these directives, thus to the very large manufacturing companies, mainly of vehicles [2] and electrical and electronic products [3]. However, because of the organisation of these industrial sectors, the constraints which apply to these very large companies are having repercussions on their suppliers, who are almost entirely SMEs. But SMEs, because of the very nature of their structure, do not, a priori, have the means necessary for integrating a new constraint, the very scope of which is beyond their field of knowledge. Moreover, experience concerning ecodesign in SMEs highlights the failure of the methods that have been used until now [4]. SMEs are finding themselves caught between the obligation being put on them by their order givers on the one hand to take into account environmental constraints in designing their products, and their inability on the other hand to meet such demands.

This problem, clearly identified, has given rise to numerous moves to develop tools and methods intended to facilitate the steps required by companies to embrace ecodesign. However, these tools and methods are firstly still those of the expert and secondly none of them serves to integrate principles (those of ecodesign) into a business. In actual fact they are support-tools considered to resolve technical problems and provide 
responses in making design choices. Convinced on the basis of our own experience on the subject that SMEs do not expect a preformatted ecodesign method, we chose to tackle the problem of ecodesign integration into SMEs from the angle of organisational change in the enterprises. Beyond the design process, it is thus a question of integrating ecodesign in the company's organisation. The method we propose is addressed not to the enterprise itself but to the external organisations that provide assistance to it at the time of an ecodesign pilot project. It is a method for guiding SMEs in conducting the change. It should lead them to integrate the relevant environmental constraints into their product's specifications, and to implement the responses adapted to this change.

\section{Critical analysis of ecodesign tools}

In this section, we illustrate that the existing ecodesign tools, besides the fact that they cannot be used as they are by people other than experts, cannot lead to permanent integration of ecodesign in a business because they were not developed for this purpose (their functionalities do not include integration in the processes of the enterprise) [5]. For more than 10 years, tools suitable for supporting the practice of ecodesign have been developed as much by academic researchers as by industry. Most often, they have even been developed in the context of partnerships through pilot projects with companies and have been run using the expertise of research centres. The variety of tools available is therefore wide. Baumann et al. [6], in one study, counted more than 150 ecodesign tools just for the design process, and to these must be added strategic tools and project organisation tools.

Fig. 1 below shows the types of ecodesign tools and how they are used in a conventional product design process. We estimate that this list is complete in as far as there is at least one ecodesign tool for each of the tasks required, if all the tasks required during a design process to integrate environmental constraints are considered. If one bears in mind, particularly, that the two axes of an ecodesign project are based firstly on environmental assessment of the product and secondly on the environmental design of this same product, two types of tools prove to be essential: tools for producing the environmental assessment and tools for guiding environmental improvement. The greatest number of ecodesign tools exist in these two categories, but there are also "related" tools, be they tools for communication, tools for helping in decisionmaking or tools assisting creativity, all conventional design tools which have been modified to include the environment component.

The list of ecodesign tools is large and varied because for each of the tool categories, there is a relatively large number of tools. The variety of tools is linked as much to the form that the tool may take (quantitative or qualitative, software or on paper, database, table, etc.) as to its purpose: a specialist tool for a given industrial sector, precision and completeness of results, etc.

\subsection{Classes of ecodesign tools}

Tools can be arranged in classes according to their characteristics and functions. Table 1 shows the different classes of tools counted and specifies, for each of them, some of their characteristics in terms of use and required expertise. The qualitative assessments of these tools are made on the basis of our own experience. The classes of tools identified in Table 1 are limited to assessment and improvement tools, specific to ecodesign. Other types of tools (aid decision-making, communication, etc.) are not listed here.

Life cycle assessment (LCA) $[7,8]$ is the reference environmental assessment tool. It is indisputable from a theoretical point of view. It is the most effective tool for environmental assessment and makes the most advanced analyses possible.

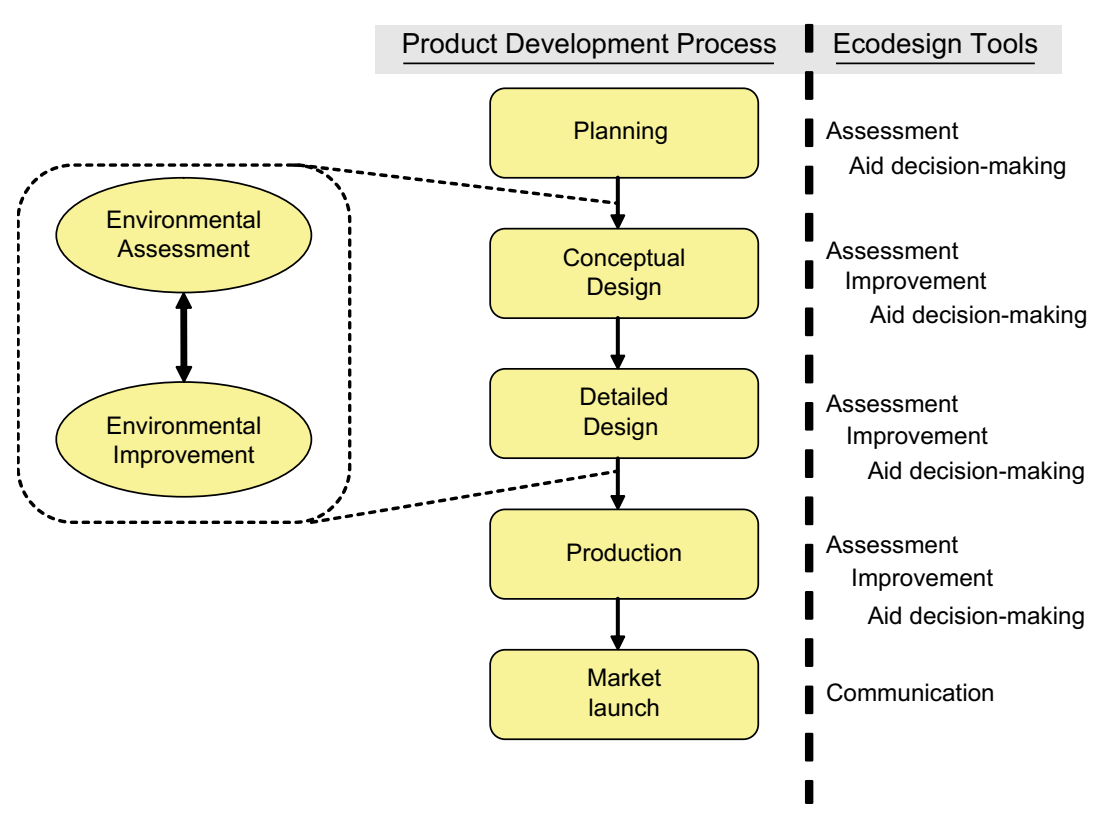

Fig. 1. Product development process and required ecodesign tools. 
Table 1

Types of ecodesign tools with their functions and characteristics

\begin{tabular}{lllll}
\hline $\begin{array}{l}\text { Types of } \\
\text { ecodesign } \\
\text { tools }\end{array}$ & $\begin{array}{l}\text { Function: } \\
\text { assessment } \\
\text { and/or } \\
\text { improvement }\end{array}$ & $\begin{array}{l}\text { Estimated } \\
\text { level of } \\
\text { required } \\
\text { expertise } \\
\text { for use }\end{array}$ & $\begin{array}{l}\text { Possible } \\
\text { autonomous } \\
\text { use by SMEs } \\
\text { (after first } \\
\text { project) }\end{array}$ & $\begin{array}{l}\text { Aid-decision } \\
\text { tool for } \\
\text { strategy }\end{array}$ \\
\hline $\begin{array}{l}\text { LCA } \\
\text { Simplified }\end{array}$ & Assessment & +++ & No & No \\
LCA & Assessment & ++ & No & No \\
$\begin{array}{l}\text { Eco-matrix } \\
\text { Checklist }\end{array}$ & Assessment & ++ & No & No \\
Eco-parametric & Assessment & + & Yes & No \\
$\begin{array}{l}\text { Impool } \\
\text { Guidelines }\end{array}$ & Improvement & + & Yes & No \\
Manual & Improvement & ++ & Yes & No \\
\hline
\end{tabular}

On the other hand it appears difficult to use in a business, as it requires so much time and expertise. It is an expert's tool above all else and its use has to be confined to research issues (academic research, R\&D).

Simplified LCAs are more user-friendly. They are based on the use of generic databases, which considerably reduce the time necessary for acquiring the data for the assessment. Nevertheless, the use of generic databases is challenging from the point of view of the scientific strictness required for the environmental assessment of products. The simplified LCA is often a good compromise between the relevance of the results provided and its potential for use in the enterprise. However, the simplified LCA remains an expert's tool and its use in SMEs is challenged by the need to have recourse to an expert and by the investment that the purchase, use and updating of a specialised software may represent. Moreover, the results of the LCA (or of the simplified LCA) define solely the levels of environmental impact that can be attributed to the product. Defining ecodesign pathways is then the result of a synthesis carried out by an expert who combines the constraints connected with regulations, the company strategy and his/her experience of the subject. This tool is therefore, for various reasons, not feasible for use by SMEs. Most of the time, simplified LCA methods propose results expressed as an ecoindicator [9]. This form of environmental assessment result as a unique indicator facilitates handling by designers. On the other hand, understanding the eco-indicator requires a solid knowledge base and interpreting it is the reserve of environment specialists.

Matrix methods may be quantitative or semi-qualitative [10-12]. The purpose of these simplified assessment methods is to limit the data collection by the manufacturer. Data are generally limited to physical dimensions such as the mass of the materials constituting the product or energy consumption. The benefit of these matrices lies in their ease of use. However, manipulation of them must be done by an environment expert who has sound knowledge of the industrial sector in which s/he is involved. If this is not the case, the assessment results may lack environmental relevance. On the one hand, these matrices pose the problem of the relevance of the expert who is using them in a given industrial sector, and secondly of the lack of participation by the company's staff in the assessment stage and in considering solutions to be developed. This last point is important because implementing a cognitive process of problem solving is a determining factor for the appropriation of the solutions [13].

As for checklists [14], they are easily used because they are lists of questions which enterprises are expected to be able to answer without difficulty. Checklists permit the product to be analysed according to functional characteristics. They do not permit environmental assessment, strictly speaking, but they have the advantage of "marking" the product so as to create reference systems in order that solutions can be compared with these reference systems, which makes them basically a tool for helping in re-designing.

Parametric assessment tools [15-17] propose simplified environmental assessments based on the mathematical relationships between parameters of the product and environmental impacts (generally expressed as eco-indicators). Their purpose is to be able to direct attention towards the best environmental solutions beginning in the conceptual design phase. These tools generally produce relatively reliable environmental assessment results because they have been developed for families of products (to one of which the product in question normally belongs). It may be considered that they are easy to use as one only has to evoke mathematical relationships, which give the environmental impacts according to the product's parameters, to identify very early in the design process the potential, future impact of the product. This type of tool is valuable for product designers because the less the structure of the product is fixed during the assessment, the more the environmental performance can be improved. However, their use is only meaningful if

- the impacts that one wishes to control for product families have been identified,

- large databases (environmental impacts/product parameters) are available for closely related products in order to establish the mathematical relationships, which connect them, with satisfactory correlations.

These cannot therefore, be generic tools but on the contrary tools which must be developed in each enterprise for cases which are specific to it. This type of tool, set as close as possible to the characteristics of the product, requires definite experience of ecodesign in the company. It may not therefore, be suitable for integrating ecodesign as a new method.

Guidelines [18,19] are the fundamental tools for the environmental improvement of products. They are a collection of general "universal" rules for ecodesign. Although simple to use, they have to be handled by people having the minimum environmental knowledge required, and above all must be supported by aids for choosing solutions such as material's databases.

Finally, the ecodesign manuals [10,20] collate the general principles of ecodesign and the basic rules for completing such a product development project by integrating environmental constraints. These manuals are reference systems and 
are too general to be used in SMEs, because they are not practical enough.

\subsection{Proposals for classifying these tools}

Tools can be classified according to several criteria characterising them: function, performance compared with the objective sought and ease of use. Several authors propose classification methods for ecodesign tools among them [16,21-23]. Table 2 summarises the classification typologies suggested by these authors. It also gives the assessment criteria to judge the tools.

Three authors Janin, Tischner and Van Berkel propose at least the two classes of tools connected with environmental assessment and improvement. It will be noticed, however, that they widen their classification field to some other classes (e.g. management or communication). Indeed, ecodesign, as a process, must be integrated into the design and management processes of the company. Not only the tools appropriate for ecodesign are needed, but also tools that can help designers make the link between their conventional tools and ecodesign. Thus, management tools, strategy tools, tools for hierarchical ordering, and communication tools are considered [21,23] as well as tools complementary to the design process such as creativity tools or decision-aid tools [22]. Janin and Van Berkel focus their classification on the performance of tools. As for Tischner, she tackles the problem of the difficulty of use linked to the time for implementing the tool, i.e. the practicality of the tool.

Dewulf suggests a different approach for classifying ecodesign tools from the other authors by focusing on support-design tools (assessment and improvement). He is interested in the types of data that must be acquired for input and the types of data that are obtained as output and their position in the design process in order to judge the relevance of these ecodesign tools in relation to each of the phases in the product design process.

\subsection{Analysis of tools and their classification by the various authors}

The contents of Table 1 show that the integration of ecodesign in a company is only possible if an expert is available. The ecodesign tools listed are tools for experts in so far as adequate knowledge and competence is needed to use them, i.e. to be able to make use of them and interpret the results according to the company's sector of activity and the product considered in the study. These experts use them in parallel with the activity carried out by the company's personnel. They only provide the results of their interpretation for staff that is not actually involved in the analysis phase of the problem for which the tools are employed. The tools cannot be used, as they are, by enterprises that do not have an expert in house, which is obviously not the case of SMEs. As Fig. 1 indicates, the implementation of an ecodesign project requires using different types of tools. The compatibility of the different tools between themselves when used on a particular project is not guaranteed and only an expert can do this.

As Zackrisson [24] underlines, the environmental domain is a complex subject and implementing environmental concerns in a business necessitates that the staff have at least a minimum of relevant experience. Tools have generally been developed by experts in the environmental analysis and ecological development of products, and the ease of these tools being used by non-experts was not considered during their development. It is clear from the information presented in Table 2 that none of the authors tackles either the problem of the difficulty of use of ecodesign tools' use (ease of handling, use, recognition of their contribution, availability of data required for providing them with information, etc.) or the problem presented by the discontinued use of types of data which are produced by using each tool: the "concepts" of these tools are not connected and their "language and vocabulary" each are foreign to the others. These two aspects mean that human expertise has to be involved to connect these "concepts" to each other and to translate the various languages that they use into a single one understandable to designers: the language of the criteria in the specifications and assessment indicators of the solutions to be employed subsequently. This need for expertise is a barrier for ecodesign integration in any company and all the more so in SMEs.

This underscores the fact that the issues concerning tool use and the compatibility of tools have not been considered to date. The reason is that authors who create and judge these tools are themselves experts and they do not experience the difficulty in using them found by non-experts. Thus, there is a lack of tools which support a company in creating and transferring to its members the knowledge which they need to pursue their ecodesign projects on their own.

Moreover, this integration cannot be considered as having been dealt with just because case studies have been conducted

Table 2

Ecodesign tool typologies and criteria for tool assessment, according to several authors

\begin{tabular}{|c|c|c|c|c|}
\hline & Janin & Tischner & Van Berkel & Dewulf \\
\hline $\begin{array}{l}\text { Criteria of tool } \\
\text { classification }\end{array}$ & $\begin{array}{l}\text { - Assessment } \\
\text { - Improvement } \\
\text { - Strategy } \\
\text { - Communication }\end{array}$ & $\begin{array}{l}\text { - Analysis (assessment) } \\
\text { - Improvement ways prioritization } \\
\text { - Aid for creativity } \\
\text { - Aid for decision-making }\end{array}$ & $\begin{array}{l}\text { - Inventory } \\
\text { - Improvement } \\
\text { - Prioritization } \\
\text { - Management }\end{array}$ & $\begin{array}{l}\text { - Life cycle global approach? } \\
\text { - Type of input data }\end{array}$ \\
\hline $\begin{array}{l}\text { Criteria suggested } \\
\text { for tool assessment }\end{array}$ & $\begin{array}{l}\text { Tool's efficiency } \\
\text { to perform its goal } \\
(0 \text { to } 5 \text { scale })\end{array}$ & $\begin{array}{l}\text { Tool's complexity } \\
\text { (required time for use) }\end{array}$ & $\begin{array}{l}\text { - Vulnerability (sensitivity) } \\
\text { - Accuracy } \\
\text { - Comprehensiveness } \\
\text { (relevance, completeness) }\end{array}$ & $\begin{array}{l}\text { - Type of outcome } \\
\text { (quantitative/qualitative) } \\
\text { - Use: which } \\
\text { stage in the design } \\
\text { process? }\end{array}$ \\
\hline
\end{tabular}


in the company [4]. Integrating a new practice or a new direction of work cannot be undertaken without a change in the business. Integration can only be considered to have taken place if indeed modifications have been durably made to certain operations carried out during product design. Ecodesign integration means going beyond a product and being interested in the organisation of the enterprise in order to modify knowledge, databases, creativity tools or even the composition of work groups.

\section{EDIMS, an integration method}

In order to respond to the shortcomings in ecodesign integration, we propose an approach to lead the change management in the company. At ENSAM Institute in Chambéry, in partnership with the Centre Technique des Industries Mécaniques (CETIM) (Technical Centre for Mechanical Industries), we have developed a method for integrating ecodesign specifically devoted to the problems encountered by SMEs. The objective of this method, developed as a software program called the EcoDesign Integration Method for SMEs (EDIMS), is to facilitate integration of ecodesign in companies. The EDIMS method is a user guide for technical centres (organisations specialised in particular sectors of activity) for assisting a company with a pilot project.

The principle of the EDIMS method is to lead the business to make its own ecodesign moves by guiding it, via one or more projects, towards a change in its work practices. EDIMS helps guide the business in making the link between the environmental constraints and its strategic preoccupations (regulations, marketing, policies).

The EDIMS method is based on the following two aspects:

- The environmental analysis of the product. This phase offers environmental analysis of the product using the expert method Typological Environmental Analysis (TEA). TEA is an environmental analysis tool that we developed at ENSAM Institute in Chambéry [25-27]. TEA is based upon the principle of the typological analysis: one type of product is linked to one type of environmental profile. TEA starts from a semi-quantitative questionnaire and uses an algorithm to carry out the typological analysis.

- Assistance in conducting change in the business, by the environmental (re)design of its product during the pilot project by:

O establishing the link between the purely environmental aspects and the strategic aspects of the business to facilitate decision-making when defining the specifications;

$\circ$ adapting the approach and the ecodesign toolbox to the enterprise and to the product. In concrete terms, this requires the staff to select the tools and indicators most relevant for the enterprise from the database available in the EDIMS program.

Fig. 2 illustrates the implementation of the EDIMS method. In the first step, the environmental analysis of the product is performed using the expert TEA method which prioritizes the environmental aspects of the product. This analysis then gives rise to a phase of redesign. The enterprise is guided in its ecodesign approach using the EDIMS method which allows it to select the information the company needs, based upon the results of the analysis.

\section{Running the method on a project: implementation}

In this section we present the principles and sequence of events in running the EDIMS method, based on the example of an electric coffee-maker.

\subsection{Context}

The EDIMS method is designed to be used in the context of advisory support given to an SME by consultants specialised in the sector of activity of the business. Because SMEs, in general, have limited financial resources for subject areas which are not directly connected with their area of skill, the time of involvement for the advisory support must be limited to a minimum, just a few work and awareness sessions of 2$4 \mathrm{~h}$ each.

\subsection{Forming a project team}

The first action of the company in the context of the pilot project is to form a project team. Particular attention must be given to form this team. Ideally it should include at least one representative per function or skill in the company. In addition to the skills connected with the design (R\&D department, manufacturing department, process design), it is necessary for other departments to be represented (purchasing, marketing, logistics departments, etc.). The integration of ecodesign in the company must be done by people with knowledge and skills and who are convinced that the approach is well founded. This means that people of strategic importance and exerting considerable weight in decision-making (typically purchasing and marketing departments) must be involved.

\subsection{Awareness}

The approach begins with an awareness meeting on environmental topics (resources, waste, energy, pollution) and ecodesign (the life cycle of products, impacts associated with products, the regulations). This meeting should be attended by the widest audience possible within the company, and not only by the project team. The presence of directors is particularly required as a sign of commitment to all the employees.

The first task of the project team, assisted by the advisors, is to choose the product from among the range of products offered by the enterprise, depending on relevant criteria such as the representativeness of the product in the range or the ease of acquiring data. 


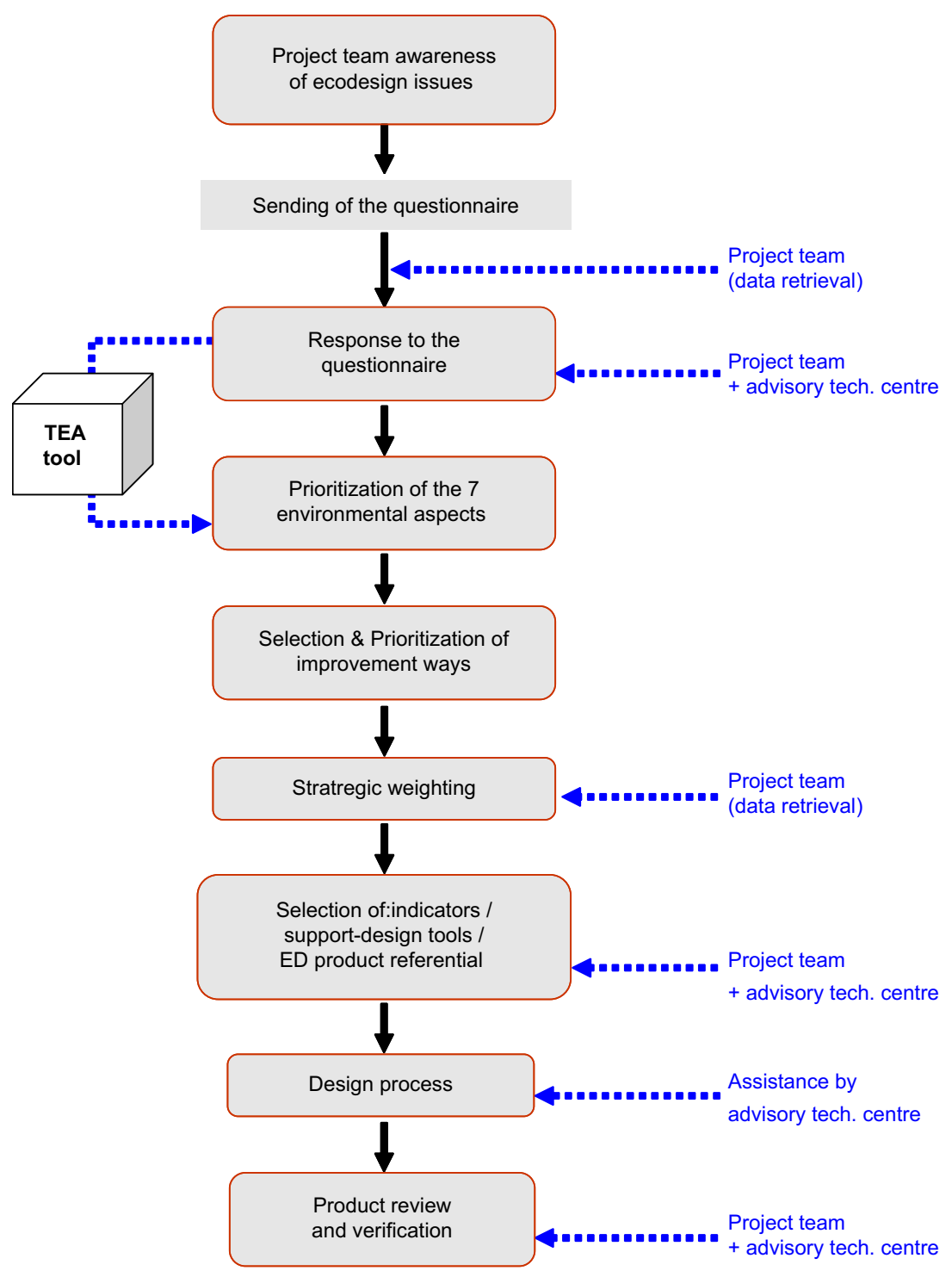

Fig. 2. Implementation of the EDIMS method for an ecodesign project with an advisory technical centre.

\subsection{The environmental analysis of the product}

The environmental analysis of the product is done using the expert TEA method. It consists in prioritizing seven environmental aspects representing the five stages in the life cycle: materials, manufacturing, use, recyclability and hazardous substances at end of life, transport and packaging. The environmental aspects are classified on a scale from 0 to 4 according to their degree of environmental priority.

As described in Refs. [25-27], the TEA tool relies on the use of a semi-quantitative questionnaire concerning the characteristics of the product, filled in jointly by the project group and the advisor. Analysis of the answers is automated as an algorithm, the rules of which are established on a knowledge database built from experience and expertise which has enabled a product typology to be created depending on its environmental impact.
The results propose a prioritization of the environmental importance of the various aspects and include an analysis of the environmental regulations connected with that product type. The final results take into account any possible regulations that should be included in the prioritization.

Fig. 3 illustrates the results of the analysis (environmental and regulatory) done with the TEA tool for the electric coffeemaker. These results are as follows:

- The three priority aspects (note 4) are the use stage of the coffee-maker and the two aspects concerning the end of life of the product, namely recyclability and hazardous substances.

- The materials aspect comes in the second group of environmental priorities (note 3 ).

- The environmental aspects concerning manufacturing, transport and packaging come lowest in order of priority. 


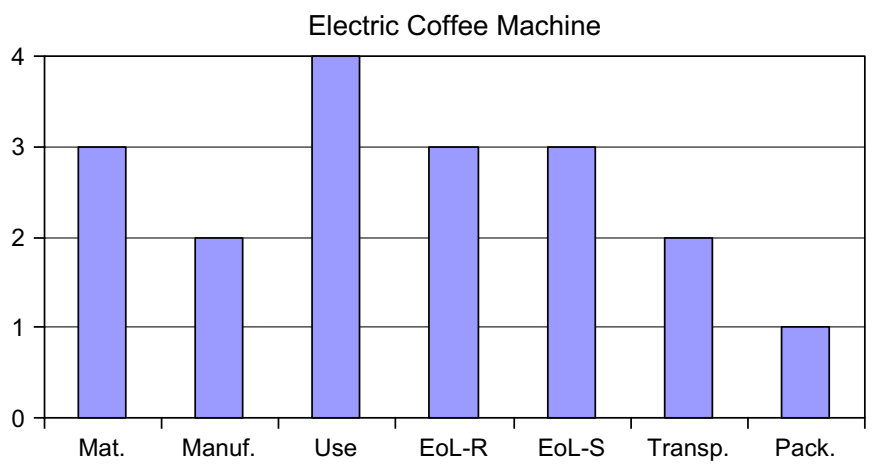

Fig. 3. Results of environmental analysis of the coffee machine with the TEA tool.

The guidelines for seeking ideas for solutions, corresponding to each of the environmental aspects, are selected and prioritized according to the answers given in the questionnaire.

\subsection{Strategic weighting of the guidelines (definition of the strategy)}

Each environmental aspect and each guideline selected are weighted by the company on the basis of strategic (regulations, marketing, etc.) and technical and economic criteria. This weighting is done by the project group and company management. Taking the example of the electric coffee-maker, the enterprise comes to the following conclusions about the prioritization:

- The aspects concerning the end of life are classified as high priority because of regulations connected with the WEEE and RoHS directives.

- The aspect "use" is not considered high priority despite its environmental importance. Indeed, the alternative technical solutions that could be envisaged for reducing consumption, provided by the guidelines, are not considered feasible at an acceptable cost.

- The aspect "materials" will be treated in as far as the subject helps meet the objectives of recyclability at the end of life at an acceptable cost.

- The packaging, although relatively unimportant from an environmental point of view, will constitute a priority axis for improvement during redesign.

- Transport is not considered to be a relevant improvement axis in the short term.

\subsection{Environmental redesign}

In the first instance, the project team defines the environmental reference, on the basis of which the product is assessed, by selecting an indicator for each of the seven environmental aspects. Then additional monitoring indicators are selected from the lists proposed, for each of the improvement axes selected by the project team. Table 3 illustrates the choice of monitoring indicators for design according to the product improvement axes selected.

\subsection{Data retrieval}

Redesign in line with these improvement axes requires seeking data concerning the product materials and its packaging. Thus, it is necessary to acquire information about the recycled content of packaging materials, the recyclability of the materials (the coffee-maker and packaging), the heavy metal content of the product (hazardous substances) and the performance of recovery chains (end of life recyclability). Identifying the data to be sought makes it possible to determine new flows of information which must be created to allow these ecodesign activities to be done for the whole product family of products being studied.

\subsection{Procedures (who does what?)}

It can be seen that setting up these new information flows, necessary for being able to fill in the indicators established by the R\&D department, concerns almost all the company's departments, and extends to the whole supply chain [28]. If the examples of data mentioned above are considered once again, it can be seen that the departments that must be involved include:

Table 3

Selected indicators for the improvement options for better environmental design of products

\begin{tabular}{|c|c|c|c|}
\hline $\begin{array}{l}\text { Environmental } \\
\text { aspect }\end{array}$ & $\begin{array}{l}\text { Selected } \\
\text { improvement } \\
\text { options }\end{array}$ & Target & $\begin{array}{l}\text { Monitoring } \\
\text { indicators }\end{array}$ \\
\hline EoL-recyclability & $\begin{array}{l}\text { Increase the } \\
\text { electric } \\
\text { coffee-maker's } \\
\text { recyclability to } \\
\text { comply with the } \\
\text { WEEE directive }\end{array}$ & $\begin{array}{l}\text { Minimum } \\
\text { recyclability } \\
\text { rate of } 50 \%\end{array}$ & $\begin{array}{l}\text { Recyclability } \\
\text { rate }(\%)\end{array}$ \\
\hline EoL-substances & $\begin{array}{l}\text { Ban or limit } \\
\text { the use of } \\
\text { hazardous } \\
\text { substances as } \\
\text { indicated } \\
\text { in the RoHS } \\
\text { directive }\end{array}$ & $\begin{array}{l}\text { - Any of the } \\
\text { following } \\
\text { substances in } \\
\text { the product: } \\
\mathrm{Cd}, \mathrm{Hg}, \mathrm{Cr} 6 \text {, } \\
\mathrm{PBDE}, \mathrm{PBB} \\
\text { - Limit Pb to } \\
\text { the exempted } \\
\text { applications } \\
\text { foreseen by } \\
\text { the directive's } \\
\text { annex }\end{array}$ & $\begin{array}{l}\text { Mass } \\
\text { concentration } \\
\text { (\% by weight) }\end{array}$ \\
\hline \multirow[t]{3}{*}{ Packaging } & $\begin{array}{l}\text { Increase the } \\
\text { packaging } \\
\text { recyclability }\end{array}$ & - & $\begin{array}{l}\text { Recyclability } \\
\text { rate }(\%)\end{array}$ \\
\hline & $\begin{array}{l}\text { Use recycled } \\
\text { materials for } \\
\text { packaging }\end{array}$ & - & $\begin{array}{l}\text { Part of } \\
\text { recycled } \\
\text { materials (\% } \\
\text { in weight) }\end{array}$ \\
\hline & $\begin{array}{l}\text { Design packaging } \\
\text { with the aim to } \\
\text { optimize logistics }\end{array}$ & $\begin{array}{l}\text { Reduce weight } \\
\text { and/or volume }\end{array}$ & $\mathrm{kg}$ and/or $\mathrm{dm}^{3}$ \\
\hline
\end{tabular}


- The Purchasing Department, which is responsible for acquiring information from suppliers of parts and components concerning:

- the possible presence of hazardous substances, and if necessary, for finding out the concentrations of them,

- the content of recycled material in these parts and components.

- The Logistics Department, which is responsible firstly for providing data concerning product logistics at the time of delivery, and secondly, should be involved in the redesign of packaging as a "customer".

- The Marketing Department, which should work out:

- the means of communicating about the environmental characteristics of the product to enhance the ecodesign work and try to profit from it in terms of sales,

- the means of informing the customer about what to do at the end of life of the product so as to improve the real level of recycling.

The manager of the group is responsible for distributing the tasks and, along with the persons in charge from the various departments concerned, for planning the modifications to be made (modification of supplier contracts for example).

\subsection{Tools}

So as to be able to implement the guidelines for redesign, the R\&D department must have certain tools at its disposal. For the example that we are looking at in this article, the tools necessary are as follows:

- a database of materials listed by the R\&D department and indicating the environmental characteristics sought in these materials: recyclability, recycled material content, net calorific value, etc.,

- tables concerning the recycling of plastics: chemical compatibility and table of densimetric sorting.

These tools, while generic (e.g. the tables concerning plastics), are in the EDIMS software and can be extracted and made directly available to the R\&D department. Certain ones, such as the materials' databases, need to be adapted according to the requirements of the enterprise. The EDIMS method provides the procedures for constituting the database.

The project group now has the conditions necessary for the environmental design of the product: the environmental objectives have been defined, the guidelines to achieve these objectives are identified, the environmental performance monitoring indicators for the product have been decided and the data to be acquired have been targeted. Finally, the R\&D department has the support-tools necessary for taking decisions relating to design choices.

Its staff can then carry through (re)design of the product, and the advisors must validate the definitive choices in order to verify that the potential environmental performance of the product has been improved.

\section{Discussion on the contribution made by the EDIMS method}

The final objective of EDIMS is the integration of ecodesign into the practices of a company by development and implementation of its own method. Beyond this objective, the ultimate objective is to spread the concepts and approaches among SMEs.

The EDIMS method provides a two-aspect response to the deficit confirmed in respect of tools:

- In the first instance it makes it possible to lift the barriers to the practice of ecodesign. These barriers are connected with the expertise required and exist both at the level of environmental assessment of the product and at the point of interpreting the results of the assessment when the former are expressed as design parameters.

- Secondly, it brings coherence to the overall ecodesign approach by making the connection between the various tools, and by guiding the change management in a way consistent with the general strategy of the business.

\subsection{Lifting the expertise barriers}

The problem of the required expertise in the environmental assessment stage is that the lack of expertise is a barrier to the participation of the company's staff in the ecodesign process and thus there is a need for knowledge and skills creation. The TEA tool, which is based on a semi-quantitative questionnaire, is a participative tool that helps in environmental knowledge creation.

It must be noted that the objective of the TEA tool is not to replace LCA. The TEA tool and LCA must be seen as complementary tools. LCA is the most effective tool for environmental assessment but is too complicated and time-consuming for SMEs. In this sense, the TEA tool is an alternative to LCA for a first ecodesign approach in SMEs.

Thus, the problem of the environmental assessment of the product is resolved by using the TEA tool which offers a relevant environmental analysis of the product expressed as a prioritization of environmental aspects.

The problem of exploiting the results is also taken into account. The EDIMS method is designed as a guide which, with the advisory support of a technical centre specialised in the company's sector of activity, can lead the company in making the link between the results of the environmental analysis of its product and the ordinary design parameters.

Therefore, EDIMS provides a solution to the problem of lack of expertise, which is generally a barrier to ecodesign integration.

\subsection{Creating a process of ecodesign integration into the company's on-going processes}

Ecodesign integration is achieved in a company when it has developed its own approach to ecodesign, i.e. when the 
company has modified not only its design process to integrate environmental constraints but also its management processes of decision-making. EDIMS is a support-method for change management that is accomplished by guiding the company to:

- define its environmental strategy in a manner consistent with its overall corporate strategy;

- modify its design process by defining indicators and support-tools for the R\&D department;

- modify and manage its information flows in order to be able to meet environmental objectives defined in the specifications;

- create the knowledge base and acquire the minimum skills so as to be able to conduct the following ecodesign projects autonomously.

Throughout the period of the company receiving advisory support on the ecodesign pilot project, the EDIMS method lets one modify the strategy, the design process and the level of knowledge within the company. The possibility of modifying these three pillars is the key to initiating the integration process in the company.

\subsection{Limitations of the EDIMS method in the integration process}

The EDIMS method is designed to be used during a pilot project, for a relatively short period (the time of involvement in this kind of operation has to be within the limits allowed by the generally restricted financial resources of SMEs). The process of integrating a totally new approach concerning an area the very idea of which is generally lacking in enterprises, is a long process. From feedback from "leader" business projects that have integrated ecodesign, the length of time necessary to take adopt an ecodesign approach is likely to be several years, i.e. a period much longer than the time planned for giving advisory support for a pilot project. That means that in implementing the pilot project with EDIMS, one cannot physically ensure the success of the integration which, if it occurs, will only be able to be verified several years later.

The EDIMS method must, during the time of a pilot project, initiate the phase of ecodesign integration by defining the strategy and modifying the design process. But nothing guarantees that this integration will become permanent, when a company must necessarily evolve dynamically (modification of statutory constraints and constraints of competition, evolution of markets, technology, etc.).

However, in the time given to a pilot project use of the EDIMS method demonstrates, on the one hand, the feasibility of such a project, and on the other hand, the strategic importance for the company to integrate ecodesign. Demonstrating this importance is probably the best guarantee for the permanent integration of ecodesign because one may reasonably suppose that if a company defines ecodesign among its strategic priorities, owing to the regulations or pressures in its market, it will provide the means necessary to achieve it.

\section{Conclusion}

This article deals with the issue of ecodesign integration in a company's organisation. In this context, we show that the ecodesign tools developed until now cannot be used because of the expertise they require in the context of integrating ecodesign in a company. Just making these tools available to a company is not enough to guarantee enduring integration. It is necessary to deal firstly with the usability of these tools by non-experts, and secondly to ensure the overall compatibility of these tools. Integration necessarily requires a change in the practices of a company. It is the very difficulty of carrying out this change, which is a barrier to ecodesign integration. The EDIMS method that we have developed initiates and guides change management in a company by establishing connections between the company's ordinary preoccupations (strategy, design) and the environmental aspects. This method should make it possible for SMEs to manage ecodesign integration into their practices.

\section{References}

[1] World commission on environment and development, WCED. Our common future, Report, United Nations; 1987.

[2] OJEU. Directive 2000/53/EC of the European Parliament and of the council of 18 September 2000 on end-of life vehicles, L 269/34; 2000.

[3] OJEU. Directive 2002/96/EC of the European Parliament and of the council of 27 January 2003 on waste electrical and electronic equipment (WEEE), L 37/24; 2003.

[4] Tukker A, Haag E, Eder P. Eco-design: European state of the art. Part I: comparative analysis and conclusions, ESTO project report, EUR 19583 EN; 2000

[5] Ammenberg J, Sundin E. Products in environmental management systems: drivers, barriers and experiences. Journal of Cleaner Production 2005; 13:405-15.

[6] Baumann H, Boons F, Bragd A. Mapping the green product development field: engineering, policy and business perspectives. Journal of Cleaner Production 2002;10:409-25.

[7] Wenzel H, Hauschild M, Alting L. Environmental assessment of products. In: Methodology, tools and case studies in product development. 2nd ed., vol. 1. Kluwer Academic Publishers; 2000. Reading, MA: Addison-Wesley.

[8] ISO 14040. Environmental management - life cycle assessment principles and framework; 1997.

[9] Goedkoop M, Effting S, Collignon M. The eco-indicator 99 - a damage oriented method for life cycle impact assessment - manual for designers, Pré consultants.

[10] Brezet H, Van Hemel C. Ecodesign - a promising approach to sustainable production and consumption. Paris: UNEP; 1997.

[11] AFNOR, FD X 30-310, Management Environnemental - Prise en compte de l'environnement dans la conception des produits - Principes généraux et applications - Lignes directrices; 1998.

[12] Graedel TE, Allenby BR. Design for environment. AT\&T, Prentice Hall; 1996.

[13] Peccei A. "Zukunfstchance Lernen", Club of Rome ûber die 80eer Jahre, Glodmann, Wien; 1979.

[14] Ventère JP. La qualité écologique des produits. AFNOR; 1995.

[15] Kaebernick H, Virginia S. An approach to simplified environmental assessment by classification of products. Proceedings of seventh CIRP life cycle seminar, Tokyo, Japan; 2000. p. 163-9.

[16] Dewulf W. A pro-active approach to ecodesign: framework and tools. $\mathrm{PhD}$ thesis, Katholieke Universiteit Leuven; 2003. 
[17] Siddhaye S, Sheng P. Environmental impact and design parameters in electronics manufacturing - a sensitivity analysis approach. Proceedings of the international symposium on electronics and the environment, May 8-10, San Francisco, USA; 2000. p. 39-45.

[18] Van Hemel CG. EcoDesign empirically explored. Design for environment in Dutch small and medium sized enterprises. PhD Thesis, Delft University of Technology; 1998.

[19] Wimmer W, Züst R. Ecodesign pilot. Product investigation, learning and optimization tool for sustainable product development. Kluwer Academic Publishers; 2001.

[20] ISO/TR 14062. Environmental management - integrating environmental aspects into product design and development; 2002.

[21] Janin M. Démarche d'éco-conception en entreprise. Un enjeu: construire la cohérence entre outils et processus. PhD thesis, ENSAM, Chambéry; 2000.

[22] Tischner U, Nickel R. Eco-design in the printing industry. Life cycle thinking: implementation of eco-design concepts and tools into the routine procedures of companies. Journal of Sustainable Product Design 2003;3:19-27.
[23] Van Berkel R, Willems E, Lafleur M. Development of an industrial ecology toolbox for the introduction of industrial ecology in enterprises $-\mathrm{I}$. Journal of Cleaner Production 1997;5:11-25.

[24] Zackrisson M. Environmental aspects when manufacturing products mainly out of metals and/or polymers. Journal of Cleaner Production 2005; 13:43-9.

[25] Le Pochat S. Ecodesign integration in the SMEs - proposition for an appropriation method lying on organizational learning processes. $\mathrm{PhD}$ thesis, Institute of Design, Mechanical Engineering \& Environment, ENSAM, Chambéry; 2005.

[26] Le Pochat S, Bertoluci G, Froelich D. An environmental analysis tool for environmental product design in SMEs. Twelfth CIRP life cycle engineering seminar, April 3-5, Grenoble, France; 2005.

[27] Le Pochat S. A tool to facilitate ecodesign integration in the SMEs. Twelfth SETAC Europe LCA case studies symposium, 10-12 January, Bologna, Italy; 2005.

[28] Le Pochat S, Bertoluci G. Consequences for businesses of taking into account environmental constraints. Proceedings of sixth international conference QMOD, October 1-3, Paris, France; 2003. 